\title{
Диагностика моральных оснований: апробация русскоязычной версии опросника MFQ
}

\author{
Олег А. Сычев ${ }^{1 *}$, Ирина Н. Протасова', Константин И. Белоусов ${ }^{2}$ \\ ${ }^{1}$ Алтайский государственный гуманитарно-педагогический университет имени \\ В.М. Шукшина, г. Бийск, Российская Федерация \\ 2 Пермский государственный национальный исследовательский университет, г. Пермь, \\ Российская Федерация \\ ${ }^{*}$ E-mail: osn1@mail.ru
}

\begin{abstract}
Аннотация
Ввеление. Разработанный на основе теории моральных оснований Аж. ХайАта «Опросник моральных оснований» (MFQ) стал популярным инструментом в зарубежных исследованиях морали. Он включает пять соответствующих моральным основаниям шкал: «забота», «справеАливосты), «лояльность группе», «уважение» и «чистота». Несмотря на умеренную належность шкал, методика может оказаться полезной Аля исслеАования моральных основ социальных стереотипов и политических убежлений в русскоязычных выборках, а также Аля разработки отечественных метолик Аиагностики моральной сореры. В Аанном исслеАовании впервые представлены психометрические характеристики русскоязычной версии опросника моральных оснований и приведены новые Аанные о связи моральных оснований с Аругими качествами.
\end{abstract}

Методы. А^я проверки валиАности преАложенной русскоязычной версии опросника моральных оснований использовались «Портретный ценностный опросник» (Ш. Шварц) и «Короткий опросник Темной триалы», направленный на измерение макиавелиизма, психопатии и нарциссизма (М. С. Егорова и Ар.). Аля анализа подверженности ответов тенденции к социальной желательности использовался опросник социальной желательности BIDR (аАаптация Е.Н. Осина). Социально-демографические характеристики были выявлены с помощью специальной анкеты.

Результаты. По итогам апробации адаптированной версии методики на выборке из 354 человек слеланы выводы об умеренной належности пяти первичных шка^ (0.62-0.68) и хорошей належности шкал второго уровня (0.79-0.84). Факторная структура русскоязычной версии показывает удовлетворительное соответствие оригиналу. Выявлена умеренная подверженность ответов тенденции к социальной желательности. Анализ валидности показал, что шкалы моральных оснований и шкалы второго уровня («этика автономии» и «этика сообщества») Аемонстрируют ожиАаемые связи с ценностями, негативными чертами личности, религиозностью и полом. 
ОбсужАение результатов. Особенностью русскоязычной версии является наличие прямых связей межАу инАивиАуализирующими и сплачивающими моральными основаниями. Тем не менее, остальные результаты хорошо соответствуют преАсказаниям теории моральных оснований и выводам, полученным в зарубежных исследованиях.

\section{КАючевые слова}

опросник моральных оснований, теория моральных оснований, забота, справеА^ивость, уважение, ^ояльность, этика автономии, этика сообщества, ценности, темная триала

\section{Основные положения}

- теория моральных оснований Аж. Хайлта является одним из наиболее перспективных направлений исслеАований в области психологии морали, поэтому актуальной является разработка русскоязычной версии опросника моральных оснований;

- русскоязычная версия опросника моральных оснований Аемонстрирует проб^ематичную належность шкал моральных оснований и высокую належность вторичных шка^, а фокторная структура показывает удовлетворительное соответствие оригиналу;

- о валиАности русскоязычной версии опросника свиАетельствуют ожиАаемые связи шкал с ценностями, негативными чертами ^ичности, религиозностью и пОАОм;

- недостатки метолики, связанные с недостаточно ясной факторной структурой и проблематичной наАежностью шка^, свидетельствуют о необходимости разработки оригинального русскоязычного опросника Аля оценки моральных оснований.

\section{Для цитирования}

Сычев О.А., Протасова И.Н., Белоусов К.И. Диагностика моральных оснований: апробация русскоязычной версии опросника MFQ // Российский психологический журнал. 2018. T. 15, № 3. С. 88-115. DOI: 10.21702/rpj.2018.3.5

Материалы статьи получены 07.02.2018 


\title{
Diagnosing Moral Foundations: Testing of the Russian Version of the Moral Foundations Questionnaire
}

\author{
Oleg A. Sychev ${ }^{1 *}$, Irina N. Protasova', Konstantin I. Belousov ${ }^{2}$ \\ ${ }^{1}$ Shukshin Altai State Humanities Pedagogical University, Biysk, Russian Federation \\ 2 Perm State National Research University, Perm, Russian Federation \\ * Corresponding author. E-mail: osn1@mail.ru
}

\begin{abstract}
Introduction. The Moral Foundations Questionnaire (MFQ), developed on the basis of $J$. Haidt's moral foundations theory, has become a popular tool for studying morality. The questionnaire contains five scales corresponding to moral foundations - namely, harm/care, fairness/reciprocity, in-group/loyalty, authority/respect, and purity/sanctity. Despite moderate reliability of the scales, the technique can be instrumental in identifying moral foundations of social stereotypes and political beliefs in Russian samples, as well as in developing Russian instruments for diagnosing individuals' morality. This study presents the psychometric characteristics of the MFQ Russian version and provides new evidence of the relationship between moral foundations and other variables.
\end{abstract}

Methods. To verify the validity of the proposed MFQ Russian version, we employed the Portrait Values Questionnaire (S. Schwartz) and the Short Dark Triad questionnaire (M.S. Egorova et al.) for measuring Machiavellianism, psychopathy, and narcissism. The Balanced Inventory of Desirable Responding (BIDR) was employed for evaluating respondents' tendency to social desirability (E.N. Osin's adaptation). Socio-demographic characteristics were identified using a special questionnaire.

Results. Testing the modified version of the questionnaire on a sample comprised of 354 individual participants showed a moderate reliability of five primary scales $(0.62-0.68)$ and a good reliability of secondary scales (0.79-0.84). The factor structure of the MFQ Russian version demonstrated a satisfactory level of matching the original technique. The respondents' answers reflected a moderate level of social desirability. The scales of moral foundations and secondary scales ('ethics of autonomy' and 'ethics of community') showed the expected relationship with values, negative personality traits, religiosity, and gender.

Discussion. The unique outcome of pilot testing of the MFQ Russian version was the demonstration of a direct relationship between the individualizing and uniting moral foundations. All other results are in good agreement with the predictions of moral foundations theory and with the conclusions of previous studies. 


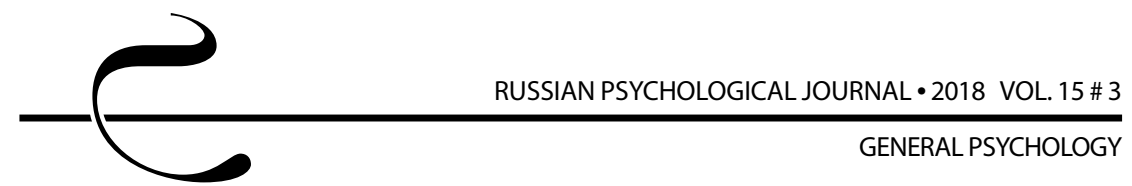

\section{Keywords}

moral foundations questionnaire, moral foundations theory, harm, fairness, authority, loyalty, ethics of autonomy, ethics of community, values, dark triad

\section{Highlights}

- J. Haidt's moral foundations theory is one of the most promising areas of research in the field of psychology of morality. The development of a Russian version of the MFQ based on its principles is an important step in advancing related research.

- The MFQ Russian version demonstrates a problematic reliability of the moral foundations scales and high reliability of the secondary scales. The factor analysis showed a satisfactory level of matching the original technique.

- Observing the expected relationship between scales and values, negative personality traits, religiosity, and gender speaks in favour of validity of the MFQ Russian version.

Disadvantages of the MFQ Russian version are associated with a lack of clear factorial structure and problematic reliability of the scales. Thus, it is important to develop an original (authentic) Russian questionnaire for diagnosing moral foundations.

\section{For citation}

Sychev O.A., Protasova I. N., Belousov K. I. Diagnosing Moral Foundations: Testing of the Russian Version of the Moral Foundations Questionnaire. Rossiiskii psikhologicheskii zhurnal - Russian Psychological Journal, 2018, V. 15, no. 3, pp. 88-115 (in Russian). DOI: 10.21702/rpj.2018.3.5

Original manuscript received 07.02.2018

\section{Введение}

Психологические и междисциплинарные исследования морали в последние десятилетия привели к появлению теории моральных оснований (TMO), предложенной Дж. Хайдтом с соавторами [1, 2, 3, 4, 5, 6]. При разработке данного подхода было предложено новое понятие моральных оснований (moral foundations) для обозначения базовых составляющих сферы морали, выступающих в качестве критериев нравственной оценки различных поступков и событий - моральных оснований для оценочных суждений.

Одним из исходных положений ТМО стала социально-интуитивистская модель морали, в соответствии с которой моральное решение принимается преимущественно на основе автоматической, интуитивной, эмоциональной оценки (moral intuition), тогда как последующие моральные рассуждения служат в основном для рационального обоснования уже принятого решения [2]. Связь моральных оценок с эмоциями и их автоматический, свернутый характер были показаны в многочисленных исследованиях (обзор см. в [3]). Эти факты позволили предположить, что в основе моральных 
оценок лежит ограниченный набор врожденных механизмов, сложившихся в ходе эволюции, причем культурное развитие морали надстраивается над этими механизмами. На основе таких представлений о природе моральных оснований (МО) для их отбора авторы ТМО выдвинули следующие критерии: наличие адаптивных преимуществ с эволюционной точки зрения, наличие врожденных основ, автоматическую (интуитивную) эмоциональную оценку, всеобщую распространенность и культурную универсальность $[4,5]$.

С опорой на перечисленные критерии к числу МО были отнесены, прежде всего, забота (включая запрет на причинение вреда) и справедливость. «Забота», по-видимому, в наибольшей мере соответствует указанным критериям: проявления заботы распространены повсеместно, при этом установлена ее связь с эмпатией и привязанностью, эволюционные аспекты которых изучены довольно подробно $[7,8]$. «Справедливость» также тесно связана с эмоциями: гневом, виной, эмпатией. Исследования взаимного альтруизма и поведения животных в ситуациях неравного вознаграждения также позволяют предполагать наличие эволюционных основ [8, 9]. «Заботу» и «справедливость» авторы ТМО назвали индивидуализирующими (individualizing) MO, поскольку именно они находились в фокусе внимания западной индивидуалистической философии морали с ее акцентом на защите прав отдельной личности [1].

По мнению авторов ТМО можно выделить еще три МО, выходящие за пределы защиты индивидуальных интересов и связанные с отношениями индивида к своей группе: лояльность группе, уважение к авторитетам и чисmomy. Преданность группе в сочетании с нетерпимостью к изменникам - эти проявления лояльности также широко распространены в современных обществах, хотя их связи с эмоциональными явлениями и эволюционные основы менее изучены. С большей уверенностью можно предполагать наличие эволюционных основ для уважения к авторитетам, готовности подчиняться и соблюдать групповую иерархию. Подобные отношения в группах были достаточно хорошо изучены на приматах [8]. «Чистота» относится к религиозным и культурным нормам и запретам в сфере отношения к пище, телу, сексу и различным сакральным для группы объектам (например, флагу или гимну). Эмоциональные механизмы этого МО связаны с отвращением [2]. Последние три MO получили название сплачивающих (binding), т. к. они способствуют сплочению группы вокруг ее ценностей и лидера.

Использующиеся в российских публикациях $[10,11]$ термины «индивидуализирующие» и «сплачивающие» МО представляют собой буквальный перевод соответствующих англоязычных понятий, введенных в ТМО. В то же время, вместо этих понятий иногда применяются предложенные ранее Р.А. Шведером категории «этика автономии» и «этика сообщества», которые 


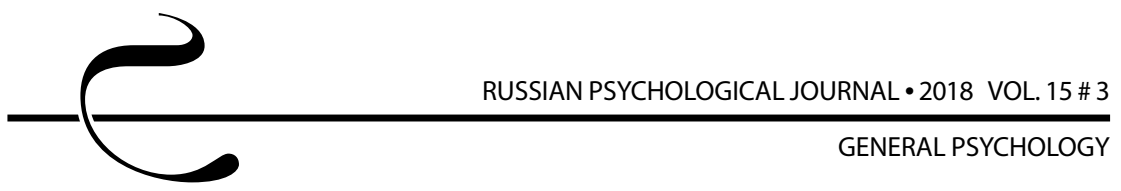

хорошо передают смысл и естественнее звучат в русском языке [12]. Далее эти две пары терминов будут использоваться нами как синонимичные.

TMO разрабатывалась для объяснения культурных инвариантов и вариаций морали, однако ее приложение к анализу моральных основ политических предпочтений также оказалось продуктивным. Эта проблема привлекла внимание после выступления американского политика П. Бьюкенена в 1992 г. о «культурной войне» в американском обществе [13], в котором он опирался на вышедшую годом ранее книгу Дж. Хантера [14]. В соответствии с позицией Дж. Хантера и П. Бьюкенена, культурная война, проявляющаяся в борьбе между лагерями консерваторов (традиционалистов) и либералов (прогрессивистов), отражает глубокие различия в моральных нормах и ценностях. В частности, для традиционалистов важнейшее значение имеют христианские ценности и строгие нормы сексуального поведения, традиционная семья и проверенные временем общественные институты. Прогрессивисты, напротив, стремятся к переменам, подрывая традиционные ценности и социальные институты, а также поддерживая «аморальные» общественные явления, связанные с защитой прав личности (такие как гомосексуальные отношения, право женщин на аборт и т. п.).

Эмпирические исследования, проведенные с помощью соответствующего опросника, показали существенное различие профилей МО у консерваторов и либералов [1]. Индивидуализирующие МО оцениваются одинаково высоко как либералами, так и консерваторами, однако только для консерваторов сплачивающие МО не менее важны, чем индивидуализирующие. Для либералов сплачивающие МO имеют существенно меньшее значение. Разность оценок индивидуализирующих и сплачивающих МО показывает столь тесную связь с политическими убеждениями, что общепринятой стала интерпретация этого показателя как коэффициента прогрессивизма.

Сравнение МО у представителей западной и восточной культур на объемной выборке, проведенное авторами методики, показало, что для лиц, проживающих в странах Азии, более важны МО лояльности и чистоты, однако величина эффекта культуры невелика. Вместе с тем эти выводы были получены в результате интернет-опроса с помощью англоязычной версии, так что в исследовании участвовали только жители азиатского региона, хорошо владеющие английским языком и поэтому, вероятно, в некоторой мере причастные к западной культуре [4].

Согласно данным авторов TMO, женщины выше ценят МО заботы, справедливости и чистоты, в то время как мужчины демонстрируют слабую тенденцию к более высокой оценке лояльности и уважения [4]. При этом наиболее велика разница в оценках мужчин и женщин по МО «забота». Кроме того, обнаружены также связи МО со свойствами личности - эмпатией [4] и свойствами 
темной триады [15]. Имеются данные о связи МО с ценностями [4], правым авторитаризмом [10], ориентацией на социальное доминирование [16], внешнеполитическими установками [17], политическими убеждениями и мнениями по спорным социально-политическим проблемам [4, 6].

Таким образом, разработка ТМО расширила теоретические представления о психологической природе и структуре морали, а также стимулировала новые эмпирические исследования. Использованию ТМО в отечественных исследованиях препятствует отсутствие соответствующего инструментария. В этой связи целью нашего исследования стала разработка русскоязычной версии опросника моральных оснований.

\section{Методы}

Для диагностики МО Дж. Грэхемом с коллегами в 2011 г. был предложен опросник (Moral Foundations Questionnaire, MFQ), который включает в себя 2 части по 15 заданий, образующих пять шкал [4]. В первой части перед испытуемым в инструкции ставится вопрос «Когда Вы решаете, что правильно, а что неправильно, какое значение имеют для Вас следующие соображения?», и предлагаются различные варианты для оценки (текст утверждений см. в таблице 2). Испытуемые оценивают каждый из 15-ти вариантов по шестибалльной шкале от «Абсолютно не важно» (0) до «Крайне важно» (5), указывая тем самым их релевантность для моральной оценки события или поступка. Во второй части испытуемые выражают меру согласия с утверждениями (по шестибалльной шкале от «Абсолютно не согласен» до «Абсолютно согласен»), воплощающими ту или иную моральную ценность.

Несмотря на свою популярность, методика MFQ имеет ряд недостатков. С психометрической точки зрения серьезной проблемой являются невысокие показатели внутренней согласованности шкал, неоднократно показанные в исследованиях $[15,18]$. Не только о психометрических, но и теоретических проблемах могут свидетельствовать трудности в подтверждении структуры методики средствами конфирматорного факторного анализа $[4,18,19,20]$.

В наших прошлых исследованиях [11] использовался перевод методики, предложенный израильским психологом Л. Боровой, размещавшийся на сайте авторов ТМО [21]. Опыт его применения побудил к разработке новой русскоязычной версии ввиду не вполне ясных формулировок инструкции и некоторых заданий. Чтобы обеспечить лингвистическую эквивалентность, была проведена процедура прямого и обратного перевода. Прямой перевод осуществлялся пятью специалистами в области английского языка, а также психологом, хорошо владеющим английским. На основе полученных шести версий (а также с учетом версии Л. Боровой) в результате обсуждения был 


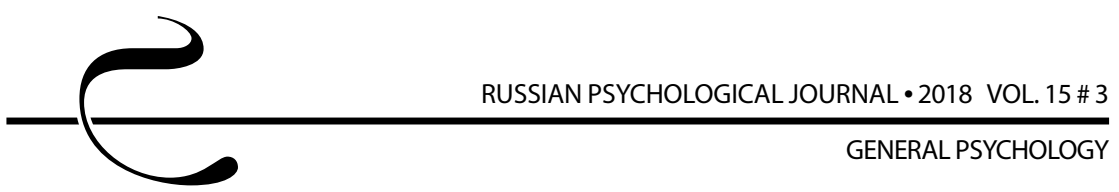

составлен итоговый вариант текста. Он был подвергнут обратному переводу носителем английского языка, хорошо владеющим русским.

Сравнение оригинальной версии методики и обратного перевода показало наличие минимальных различий, не искажающих смысла. Единственное отличие связано с утверждением из шкалы чистоты, содержащим английское слово «chastity», наиболее точным переводом которого является книжное слово «целомудрие». Это слово вызывает вопросы у некоторых испытуемых, поэтому вместо него было использовано понятие «нравственная чистота».

Ввиду отсутствия надежных и валидных русскоязычных методик, измеряющих те же конструкты, что и MFQ, в ходе исследования валидности русскоязычной версии (MFQ-Ru) использовался комплекс методик, измеряющих особенности личности, связь которых с МО была ранее показана в зарубежных исследованиях, в частности, обобщенные ценности и негативные черты личности [4, 15 и др.].

Портретный ценностный опросник Ш. Шварца (PVQ-R2), основанный на его уточненной теории базовых индивидуальных ценностей, позволяет получить оценки значимости для 19-ти базовых ценностей, располагающихся в круговом континууме [22]. На основе 19-ти первичных ценностных шкал вычисляются 4 вторичных показателя, отражающих обобщенные ценности: самоутверждение, самопреодоление, открытость изменениям, сохранение. С учетом результатов, полученных авторами MFQ [4], можно ожидать, что ценности самопреодоления, включающие заботу об окружающих и о природе, должны показать прямую связь с МО «забота», в то время как ценности самоутверждения, включающие личные достижения, доминирование, обладание ресурсами, напротив, должны показывать обратную связь с МО «забота» и «справедливость». Ценности сохранения и открытости изменениям позволяют проверить вытекающее из теории моральных оснований предположение о связи сплачивающих МО с консерватизмом и прогрессивизмом.

Для оценки психопатии и близких к ней негативных черт личности, связанных с низким уровнем нравственности, использовался короткий опросник Темной триады, направленный на измерение макиавеллизма, психопатии и нарциссизма, в адаптации М.С. Егоровой с соавторами [23]. Данный опросник был выбран для анализа валидности в связи с тем, что он позволяет измерить негативные качества личности по определению связанные с «дефицитом» морали, причем данное предположение было доказано с помощью аналогичных методик в зарубежных исследованиях [15].

Поскольку моральные качества личности имеют большую социальную значимость, можно предполагать, что результаты испытуемых по методике MFQ-Ru будут подвержены влиянию установки на социально желательные ответы. Для проверки этого предположения использовался опросник 
социальной желательности BIDR (Balanced Inventory of Desirable Responding) в адаптации Е.Н. Осина [24]. В структуру опросника входят шкалы самообмана-приукрашивания, управления впечатлениями, самообмана-отрицания.

Для сбора данных о социально-демографических характеристиках испытуемых использовалась анкета, включающая вопросы относительно пола, возраста, места жительства (город или село), материального положения семьи и религиозности. Для выяснения религиозности использовался вопрос из исследования «Глобальный индекс религиозности и атеизма» фонда «WIN/Gallup International»: «Вне зависимости от того, посещаете ли Вы места общественного богослужения или нет, Вы считаете себя а) религиозным человеком, б) нерелигиозным человеком, в) убежденным атеистом, г) затрудняюсь ответить» [25]. Для оценки степени религиозности задавался дополнительный вопрос: «Если Вы считаете себя религиозным человеком, укажите, пожалуйста, как часто в среднем Вы посещаете храм?». На основе ответов на эти два вопроса определялся уровень религиозности в порядковой шкале от 1 до 5: 1 - нерелигиозный или атеист; 2 - верующий, но храм не посещает; 3 - верующий, храм посещает редко (несколько раз в год или реже); 4 - верующий, храм посещает не реже раза в месяц; 5 - верующий, храм посещает не реже раза в неделю.

Для решения задач, связанных с анализом надежности и структуры опросника, использовалась выборка из 354 испытуемых, включающая в себя преимущественно студентов и преподавателей вузов городов Бийска и Перми. Возраст испытуемых лежал в пределах от 17 до 60 лет ( $M=24.34$; $S D=7.74)$, большинство испытуемых - женщины (71 \%). Для анализа валидности методики часть этой выборки наряду с опросником МО заполняла указанные выше методики. Эта выборка валидизации включала 223 человека в возрасте от 17 до 60 лет (средний возраст $M=26.07 ; S D=8.30$ ), доля женщин - 69\%, доля лиц, проживающих в городе - 77.6\%. Основная часть этой выборки (81 \%) - студенты очного и заочного отделений АГГПУ и ПГНИУ, а также сотрудники этих вузов. По сокращенной батарее, включающей MFQ-Ru и PVQ-R2 вместе с анкетой о социально-демографических характеристиках, прошли обследование 25 (10\% выборки) прихожан религиозной организации Евангельских христиан церкви «Новое поколение» и 22 (9\%) клиента реабилитационного центра Межрегиональной общественной организации «Скажи жизни “Да"» (г. Бийск), проходящих лечение от наркотической и алкогольной зависимости.

\section{Результаты}

Проверка нормальности распределения данных показала умеренные отличия от нормального: значения критерия Шапиро -Уилка лежат в пределах 
от 0.976 до 0.991 ( $p$ < 0.05). Распределение большинства шкал характеризуется слабой отрицательной асимметрией, что говорит о большей частоте высоких оценок (таблица 1). Значения коэффициентов надежности (а Кронбаха) несколько ниже тех, о которых сообщают авторы методики, однако соответствуют величинам, полученным на европейских версиях методики $[18,19]$. Для четырех из пяти шкал моральных оснований (кроме шкалы «уважение») значения альфа Кронбаха лежат в пределах 0.65-0.70, что соответствует «минимально приемлемому» уровню надежности [26, с. 85].

Теоретические положения, выводы из предшествующих исследований и результаты факторного анализа наших данных (см. далее) позволяют говорить о наличии двух надежных шкал второго уровня, объединяющих индивидуалистические МО (шкала «этика автономии») и сплачивающие MO (шкала «этика сообщества»). Следовательно, предложенная версия позволяет получить весьма надежные оценки по шкалам второго уровня, а первичные шкалы могут использоваться в исследовательских целях с учетом их минимально допустимой или сомнительной (шкала «уважение») надежности.

Таблица 1. Описательная статистика, належность и интеркорреляции шкал метоАики MFQ-RU ( $N=354)$

Table 1. Descriptive statistics, reliability and intercorrelation of the MFQ-RU scales $(\mathrm{N}=354)$

\begin{tabular}{|c|c|c|c|c|c|c|c|}
\hline $\begin{array}{c}\text { Шкалы } \\
\text { и показатели } \\
\text { Scales \& scores }\end{array}$ & $\begin{array}{c}\text { Забота } \\
\text { Care }\end{array}$ & $\begin{array}{c}\text { Cпра- } \\
\text { веАли- } \\
\text { вость } \\
\text { Fair- } \\
\text { ness }\end{array}$ & $\begin{array}{l}\text { ヘояль- } \\
\text { Ность } \\
\text { Loya- } \\
\text { Ity }\end{array}$ & $\begin{array}{l}\text { Ува- } \\
\text { же- } \\
\text { ниe } \\
\text { Res- } \\
\text { pect }\end{array}$ & $\begin{array}{l}\text { Чис- } \\
\text { тота } \\
\text { Purity }\end{array}$ & $\begin{array}{l}\text { Этика } \\
\text { авто- } \\
\text { номии } \\
\text { Ethics } \\
\text { of } \\
\text { auto- } \\
\text { nomy }\end{array}$ & $\begin{array}{c}\text { Этика } \\
\text { сооб- } \\
\text { щества } \\
\text { Ethics of } \\
\text { community }\end{array}$ \\
\hline $\begin{array}{l}\text { Забота } \\
\text { Care }\end{array}$ & - & & & & & & \\
\hline $\begin{array}{l}\text { Справел- } \\
\text { ливость } \\
\text { Fairness }\end{array}$ & $0.64^{* * *}$ & - & & & & & \\
\hline $\begin{array}{l}\text { АОя^ьность } \\
\text { Loyalty }\end{array}$ & $0.33^{* * *}$ & $0.29 * * *$ & - & & & & \\
\hline $\begin{array}{l}\text { Уважение } \\
\text { Respect }\end{array}$ & $0.20^{* * *}$ & $0.15^{* *}$ & $0.68^{* * *}$ & - & & & \\
\hline
\end{tabular}


ОБЩАЯ ПСИХОЛОГИЯ

\begin{tabular}{|c|c|c|c|c|c|c|c|}
\hline $\begin{array}{c}\text { Шкалы } \\
\text { и показатели } \\
\text { Scales \& scores }\end{array}$ & $\begin{array}{c}\text { Забота } \\
\text { Care }\end{array}$ & $\begin{array}{c}\text { Cпра- } \\
\text { веААи- } \\
\text { вость } \\
\text { Fair- } \\
\text { ness }\end{array}$ & $\begin{array}{l}\text { Аоямь- } \\
\text { НОсть } \\
\text { Loya- } \\
\text { Ity }\end{array}$ & $\begin{array}{l}\text { Ува- } \\
\text { же- } \\
\text { ние } \\
\text { Res- } \\
\text { pect }\end{array}$ & $\begin{array}{l}\text { Чис- } \\
\text { тота } \\
\text { Purity }\end{array}$ & $\begin{array}{c}\text { Этика } \\
\text { वвто- } \\
\text { номии } \\
\text { Ethics } \\
\text { of } \\
\text { auto- } \\
\text { nomy }\end{array}$ & $\begin{array}{c}\text { Этика } \\
\text { сооб- } \\
\text { щества } \\
\\
\text { Ethics of } \\
\text { community }\end{array}$ \\
\hline $\begin{array}{l}\text { Чистота } \\
\text { Purity }\end{array}$ & $0.48^{* * *}$ & $0.38^{* * *}$ & $0.49^{* * *}$ & $0.52^{* * *}$ & - & & \\
\hline $\begin{array}{l}\text { Этика } \\
\text { автономии } \\
\text { Ethics of } \\
\text { autonomy }\end{array}$ & $0.92^{* * *}$ & $0.89^{* * *}$ & $0.34^{* * *}$ & $0.19^{* * *}$ & $0.47^{* * *}$ & - & \\
\hline $\begin{array}{l}\text { Этика } \\
\text { сообщества } \\
\text { Ethics of } \\
\text { community }\end{array}$ & $0.40^{* * *}$ & $0.33^{* * *}$ & $0.86^{* * *}$ & $0.87^{* * *}$ & $0.80^{* * *}$ & $0.40^{* * *}$ & - \\
\hline $\begin{array}{l}\text { Належность } \\
\text { (а Кронбаха) } \\
\text { Reliability } \\
\text { (Cronbach's } \\
\text { alpha) }\end{array}$ & 0.66 & 0.66 & 0.66 & 0.62 & 0.68 & 0.79 & 0.84 \\
\hline $\begin{array}{l}\text { Коэфффициент } \\
\text { асимметрии } \\
\text { Skewness }\end{array}$ & -0.53 & -0.31 & -0.22 & -0.04 & -0.30 & -0.42 & 0.05 \\
\hline $\begin{array}{l}\text { Среднее } \\
\text { значение } \\
\text { Mean score }\end{array}$ & 3.50 & 3.53 & 2.94 & 2.67 & 3.15 & 3.52 & 2.92 \\
\hline $\begin{array}{l}\text { СтанА. } \\
\text { отк^онение } \\
\\
\text { Standard } \\
\text { deviation }\end{array}$ & 0.76 & 0.67 & 0.76 & 0.74 & 0.78 & 0.65 & 0.64 \\
\hline
\end{tabular}

Примечание. Уровень значимости коррелячий: ${ }^{*}-p<0.05 ;{ }^{* *}-p<0.01 ;{ }^{* * *}-p<0.001$. Note. Significance of correlations: ${ }^{*}-p<0.05 ;^{* *}-p<0.01 ;^{* * *}-p<0.001$. 
Анализ структуры опросника с помощью конфирматорного факторного анализа не проводился, поскольку в оригинальной версии факторные модели, как правило, показывают не вполне удовлетворительное соответствие данным [4, 18, 19, 20]. Для сравнения факторной структуры русскоязычной и оригинальной версий был выполнен эксплораторный факторный анализ методом главных факторов с вращением «varimax» с помощью пакета psych в программе R, результаты которого представлены в таблице 2. Далее средствами этого пакета полученное решение сравнивалось с факторной структурой оригинальной версии методики [4] с помощью коэффициента конгруэнтности Такера [27]. Величина коэффициента конгруэнтности для первого фактора (сплачивающих МO) составила 0.90, для второго фактора (индивидуализирующих МO): 0.86. Эти значения позволяют сделать вывод об удовлетворительном воспроизведении факторной структуры в русскоязычной версии.

Таблица 2. Результаты эксплораторного фракторного анализа заланий MFQ-RU $(\mathrm{N}=354)$

Table 2. Exploratory factor analysis of $M F Q-R U$ items ( $N=354)$

\begin{tabular}{|c|c|c|c|c|}
\hline \multirow{2}{*}{ № } & \multirow{2}{*}{$\begin{array}{c}\text { Текст утверждения } \\
\text { Statement text }\end{array}$} & \multirow{2}{*}{$\begin{array}{l}\text { Шкала } \\
\text { Scale }\end{array}$} & \multicolumn{2}{|c|}{$\begin{array}{c}\text { Факторные } \\
\text { нагрузки } \\
\text { Factor loads }\end{array}$} \\
\hline & & & $\begin{array}{c}\text { Фактор } 1 \\
\text { Factor } 1\end{array}$ & $\begin{array}{l}\text { Фактор } 2 \\
\text { Factor } 2\end{array}$ \\
\hline \multicolumn{5}{|c|}{ Часть 1} \\
\hline 1 & $\begin{array}{l}\text { Испыта^ ^и кто-нибудь от этого } \\
\text { поступка Аушевные страАания }\end{array}$ & \multirow{3}{*}{ Забота } & $\begin{array}{l}-0.01 \\
(0.01)\end{array}$ & $\begin{array}{c}0.49 \\
(0.59)\end{array}$ \\
\hline 7 & $\begin{array}{l}\text { Бы^а ^и проявлена забота } \\
\text { о слабых и беззащитных }\end{array}$ & & $\begin{array}{c}0.15 \\
(0.09)\end{array}$ & $\begin{array}{c}0.53 \\
(0.65)\end{array}$ \\
\hline 12 & Бы^а ^и проявлена жестокость & & $\begin{array}{l}-0.09 \\
(0.07)\end{array}$ & $\begin{array}{c}\mathbf{0 . 7 6} \\
(0.59)\end{array}$ \\
\hline 8 & $\begin{array}{l}\text { Бы^ ^и этот поступок } \\
\text { несправеАливым }\end{array}$ & \multirow{3}{*}{ СправеАливость } & $\begin{array}{l}-0.12 \\
(0.01)\end{array}$ & $\begin{array}{l}0.70 \\
(0.56)\end{array}$ \\
\hline 2 & $\begin{array}{l}\text { Отнеслись ^и при этом к кому- } \\
\text { нибудь необъективно }\end{array}$ & & $\begin{array}{l}-0.13 \\
(0.11)\end{array}$ & $\begin{array}{c}\mathbf{0 . 4 8} \\
(0.59)\end{array}$ \\
\hline 13 & $\begin{array}{l}\text { Были ^и ущемлены чьи-либо } \\
\text { права }\end{array}$ & & $\begin{array}{l}-0.11 \\
(0.18)\end{array}$ & $\begin{array}{c}0.72 \\
(0.47)\end{array}$ \\
\hline
\end{tabular}


ОБЩАЯ пСИХОЛОГИЯ

\begin{tabular}{|c|c|c|c|c|}
\hline 14 & $\begin{array}{l}\text { Бы^о ^и прояв^ено отсутствие } \\
\text { преданности своей группе }\end{array}$ & \multirow{3}{*}{ АОяАЬНОСть } & $\begin{array}{c}0.39 \\
(0.52)\end{array}$ & $\begin{array}{l}0.36 \\
(0.19)\end{array}$ \\
\hline 9 & ПреАа^ ^и кто-то свой ко^^ектив & & $\begin{array}{c}0.23 \\
(0.48)\end{array}$ & $\begin{array}{l}0.46 \\
(0.17)\end{array}$ \\
\hline 3 & $\begin{array}{l}\text { Прояви^ась ^и в этом поступке } \\
\text { ^юбовь к своей стране }\end{array}$ & & $\begin{array}{l}\mathbf{0 . 5 5} \\
(0.67)\end{array}$ & $\begin{array}{l}0.16 \\
(0.02)\end{array}$ \\
\hline 10 & $\begin{array}{l}\text { СоблюАались ии обычаи } \\
\text { и традиции }\end{array}$ & \multirow{3}{*}{ Уважение } & $\begin{array}{c}\mathbf{0 . 5 1} \\
(0.61)\end{array}$ & $\begin{array}{c}0.15 \\
(0)\end{array}$ \\
\hline 4 & $\begin{array}{l}\text { Бы^о ^и продемонстрировано } \\
\text { неуважение к в^асти }\end{array}$ & & $\begin{array}{c}0.57 \\
(0.69)\end{array}$ & $\begin{array}{l}0.06 \\
(0.05)\end{array}$ \\
\hline 15 & $\begin{array}{l}\text { Приве^ ^и этот поступок к хаосу } \\
\text { или беспоряАку }\end{array}$ & & $\begin{array}{c}0.11 \\
(0.40)\end{array}$ & $\begin{array}{c}0.47 \\
(0.20)\end{array}$ \\
\hline 11 & $\begin{array}{l}\text { Бы^о ^и в этом поступке что-то } \\
\text { отвратительное }\end{array}$ & \multirow{3}{*}{ Чистота } & $\begin{array}{l}0.10 \\
(0.57)\end{array}$ & $\begin{array}{c}0.59 \\
(0.21)\end{array}$ \\
\hline 5 & $\begin{array}{l}\text { Нарушались ^и при этом } \\
\text { нормы морали и приличия }\end{array}$ & & $\begin{array}{c}0.17 \\
(0.70)\end{array}$ & $\begin{array}{l}0.55 \\
(0.10)\end{array}$ \\
\hline 16 & $\begin{array}{l}\text { Бы^ ^и этот поступок } \\
\text { богоугоАным }\end{array}$ & & $\begin{array}{c}0.52 \\
(0.64)\end{array}$ & $\begin{array}{c}0.05 \\
(0.02)\end{array}$ \\
\hline \multicolumn{5}{|c|}{ Часть 2} \\
\hline 23 & $\begin{array}{l}\text { ОАин из хулших поступков - } \\
\text { обилеть беззащитное животное }\end{array}$ & \multirow{3}{*}{ Забота } & $\begin{array}{c}0.11 \\
(0.01)\end{array}$ & $\begin{array}{l}0.36 \\
(0.39)\end{array}$ \\
\hline 28 & $\begin{array}{l}\text { Нельзя найти оправлание } \\
\text { убийству человека }\end{array}$ & & $\begin{array}{c}0.22 \\
(0.07)\end{array}$ & $\begin{array}{c}0.22 \\
(0.35)\end{array}$ \\
\hline 17 & $\begin{array}{l}\text { Сострадание - самая важная } \\
\text { добродетель }\end{array}$ & & $\begin{array}{c}0.33 \\
(0.01)\end{array}$ & $\begin{array}{l}0.34 \\
(0.63)\end{array}$ \\
\hline 24 & $\begin{array}{l}\text { Справедливость - основное, что } \\
\text { необхоАимо Аля общества }\end{array}$ & \multirow{3}{*}{ СправеАливость } & $\begin{array}{c}0.21 \\
(0.09)\end{array}$ & $\begin{array}{c}0.43 \\
(0.27)\end{array}$ \\
\hline 18 & $\begin{array}{l}\text { В законах важнее всего - } \\
\text { гарантия, что с кажАым будут } \\
\text { поступать справеААиво }\end{array}$ & & $\begin{array}{c}0.23 \\
(0.14)\end{array}$ & $\begin{array}{c}0.37 \\
(0.48)\end{array}$ \\
\hline 29 & $\begin{array}{l}\text { я думаю, неправильно, что } \\
\text { богатые дети наследуют много } \\
\text { денег, в то время как белные } \\
\text { не наследуют ничего }\end{array}$ & & $\begin{array}{c}0.21 \\
(0.22)\end{array}$ & $\begin{array}{c}0.22 \\
(0.38)\end{array}$ \\
\hline
\end{tabular}




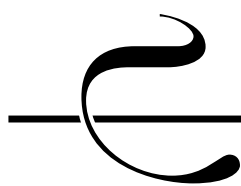

RUSSIAN PSYCHOLOGICAL JOURNAL・ 2018 VOL. 15 \# 3

GENERAL PSYCHOLOGY

\begin{tabular}{|c|c|c|c|c|}
\hline 30 & $\begin{array}{l}\text { Быть частью команды важнее } \\
\text { самовыражения }\end{array}$ & \multirow{3}{*}{ АОя^ьНОСТЬ } & $\begin{array}{c}0.49 \\
(0.45)\end{array}$ & $\begin{array}{l}-0.06 \\
(0.03)\end{array}$ \\
\hline 19 & $\begin{array}{l}\text { Я горжусь историей своей } \\
\text { страны }\end{array}$ & & $\begin{array}{c}\mathbf{0 . 5 2} \\
(0.49)\end{array}$ & $\begin{array}{c}0.16 \\
(0.18)\end{array}$ \\
\hline 25 & $\begin{array}{l}\text { ^юАи Аолжны быть преАаны } \\
\text { своим близким, Ааже если } \\
\text { те совершили что-то плохое }\end{array}$ & & $\begin{array}{c}\mathbf{0 . 4 2} \\
(0.34)\end{array}$ & $\begin{array}{l}0.06 \\
(0.04)\end{array}$ \\
\hline 26 & $\begin{array}{l}\text { Мужчины и женщины играют } \\
\text { разные роли в обществе }\end{array}$ & \multirow{3}{*}{ Уважение } & $\begin{array}{c}0.40 \\
(0.47)\end{array}$ & $\begin{array}{l}-0.08 \\
(0.24)\end{array}$ \\
\hline 31 & $\begin{array}{l}\text { Если бы я был солАатом } \\
\text { и не согласился с приказами } \\
\text { моего команАира, я бы все } \\
\text { равно им поАЧини^ся, потому } \\
\text { Что Это мой АОАг }\end{array}$ & & $\begin{array}{c}0.49 \\
(0.48)\end{array}$ & $\begin{array}{l}0.03 \\
(0.20)\end{array}$ \\
\hline 20 & $\begin{array}{l}\text { Уважение к в^асти } \\
\text { и к авторитету - это то, чему } \\
\text { Аолжны учиться все Аети }\end{array}$ & & $\begin{array}{c}0.61 \\
(0.64)\end{array}$ & $\begin{array}{l}-0.06 \\
(0.05)\end{array}$ \\
\hline 21 & $\begin{array}{l}\text { ^юАи не Аолжны совершать } \\
\text { отвратительные поступки, Ааже } \\
\text { если они никому не приносят } \\
\text { вреда }\end{array}$ & \multirow{3}{*}{ Чистота } & $\begin{array}{c}0.40 \\
(0.66)\end{array}$ & $\begin{array}{c}0.32 \\
(0.03)\end{array}$ \\
\hline 27 & $\begin{array}{l}\text { я бы назвал некоторые поступки } \\
\text { неправильными, потому что они } \\
\text { противоестественны }\end{array}$ & & $\begin{array}{c}0.50 \\
(0.66)\end{array}$ & $\begin{array}{c}0.04 \\
(0.07)\end{array}$ \\
\hline 32 & $\begin{array}{l}\text { Нравственная чистота - важная } \\
\text { и ценная Аобролетель }\end{array}$ & & $\begin{array}{c}0.49 \\
(0.67)\end{array}$ & $\begin{array}{c}0.27 \\
(0.08)\end{array}$ \\
\hline
\end{tabular}

Примечание: в скобках для сравнения приведены нагрузки по данным Дж. Грэхема и др. (2011 г.), порядок утверждений как в упомянутой статье. Предназначенные для оченки достоверности ответов задания №№ 6 и 22 в факторном анализе не учитывались и в табличе не приводятся. Нагрузки, равные или превышающие 0.40, выделены жирным шрифтом. 
ОБЩАЯ ПСИХОЛОГИЯ

Моральные качества имеют большое значение в межличностных отношениях и выступают важным критерием социальной оценки личности. В этой связи можно предположить, что результаты по методике MFQ-Ru подвержены влиянию установки на социально желательные ответы. Это предположение подтверждается результатами корреляционного анализа шкал социальной желательности и МO (таблица 3).

Таблица 3. Корреляции моральных оснований со шкалами социальной желательности, обобщенными ценностями и чертами темной триалы

Table 3. Correlations between moral foundations and the scales of social desirability, generalized values, and the dark triad traits

\begin{tabular}{|c|c|c|c|c|c|c|c|}
\hline & \multicolumn{7}{|c|}{$\begin{array}{l}\text { Шкалы MFQ-RU } \\
\text { MFQ-RU Scales }\end{array}$} \\
\hline & $\begin{array}{c}\text { Забота } \\
\text { Care }\end{array}$ & $\begin{array}{c}\text { Cпра- } \\
\text { веАли- } \\
\text { вость } \\
\text { Fairness }\end{array}$ & $\begin{array}{l}\text { ヘоя^ь- } \\
\text { ность } \\
\text { Loyalty }\end{array}$ & 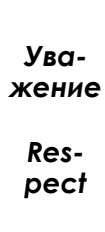 & $\begin{array}{l}\text { Чис- } \\
\text { тота } \\
\text { Purity }\end{array}$ & $\begin{array}{l}\text { Этика } \\
\text { वвто- } \\
\text { номии } \\
\\
\text { Ethics } \\
\text { of auto- } \\
\text { nomy }\end{array}$ & $\begin{array}{c}\text { Этика } \\
\text { сооб- } \\
\text { щества } \\
\text { Ethics of } \\
\begin{array}{c}\text { commu- } \\
\text { nity }\end{array}\end{array}$ \\
\hline \multicolumn{8}{|c|}{ Шкалы социальной желательности (N = 202) } \\
\hline $\begin{array}{l}\text { Шкала } \\
\text { самооб- } \\
\text { мана- } \\
\text { приукра- } \\
\text { шивания } \\
\\
\text { Self- } \\
\text { Deceptive } \\
\text { Enhan- } \\
\text { cement }\end{array}$ & 0.05 & 0.04 & $0.20^{* *}$ & $0.25^{* *}$ & $0.20 * *$ & 0.05 & $0.27^{* *}$ \\
\hline $\begin{array}{l}\text { Шкала } \\
\text { управ- } \\
\text { ^ения } \\
\text { впечат- } \\
\text { ^ениями } \\
\text { Impression } \\
\text { Manage- } \\
\text { ment }\end{array}$ & 0.15 & 0.11 & 0.14 & $0.22^{* *}$ & $0.20^{*}$ & 0.14 & $0.23^{* *}$ \\
\hline
\end{tabular}




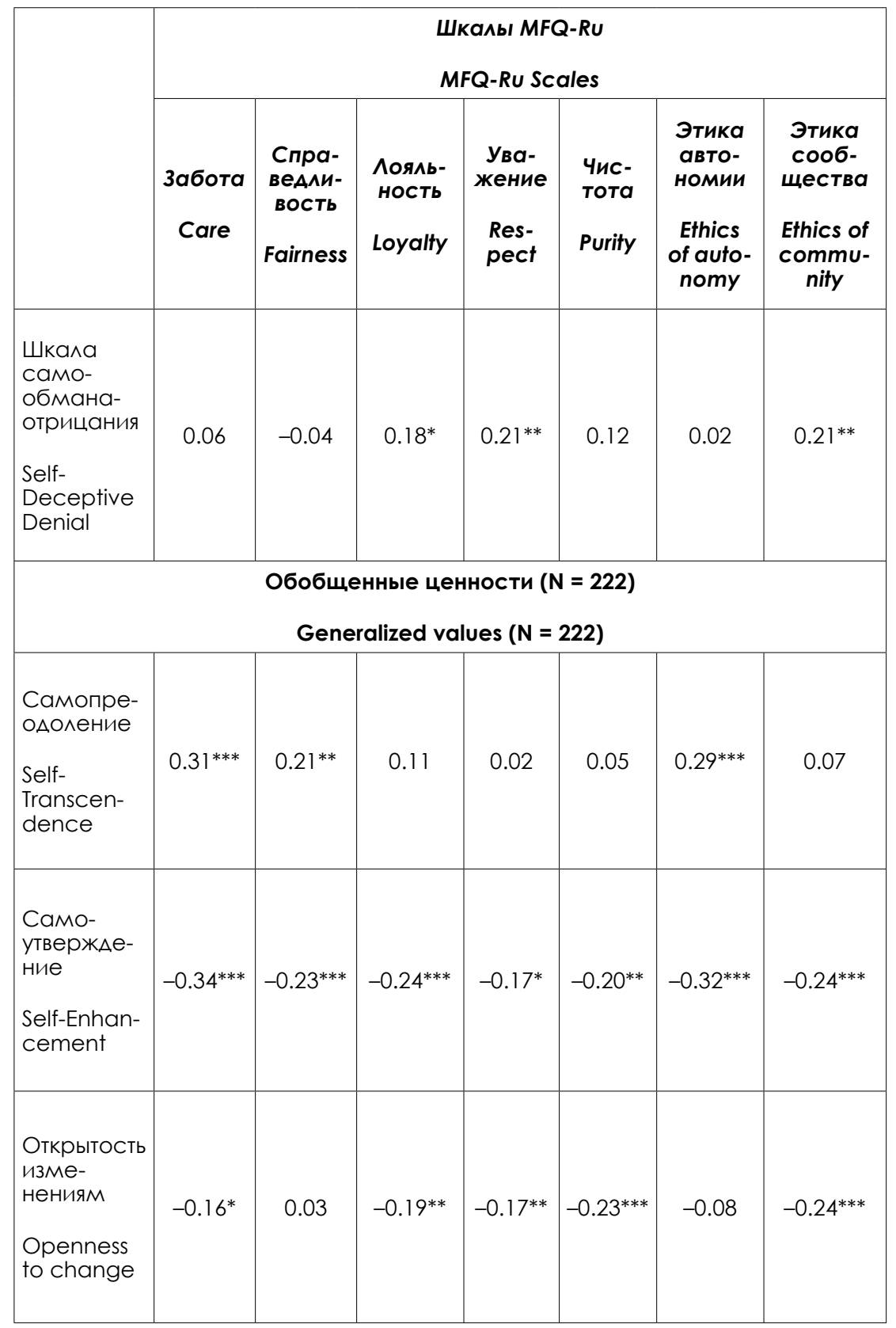




\begin{tabular}{|c|c|c|c|c|c|c|c|}
\hline & \multicolumn{7}{|c|}{$\begin{array}{l}\text { Шкалы MFQ-Ru } \\
\text { MFQ-Ru Scales }\end{array}$} \\
\hline & $\begin{array}{l}\text { Забота } \\
\text { Care }\end{array}$ & $\begin{array}{c}\text { Спра- } \\
\text { веАли- } \\
\text { вость } \\
\text { Fairness }\end{array}$ & $\begin{array}{l}\text { ヘояАь- } \\
\text { Ность }\end{array}$ & 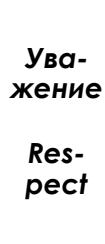 & $\begin{array}{l}\text { Чис- } \\
\text { тота } \\
\text { Purity }\end{array}$ & $\begin{array}{c}\text { Этика } \\
\text { वвто- } \\
\text { номии } \\
\\
\text { Ethics } \\
\text { of auto- } \\
\text { nomy }\end{array}$ & $\begin{array}{c}\text { Этика } \\
\text { сооб- } \\
\text { щества } \\
\text { Ethics of } \\
\text { commu- } \\
\text { nity }\end{array}$ \\
\hline $\begin{array}{l}\text { Coxpa- } \\
\text { HeHne } \\
\text { Conser- } \\
\text { vation }\end{array}$ & $0.19^{* *}$ & 0.04 & $0.28^{* * *}$ & $0.27^{* * *}$ & $0.30^{* * *}$ & $0.14^{*}$ & $0.34^{* * *}$ \\
\hline \multicolumn{8}{|c|}{$\begin{array}{c}\text { Черты темной триаАы }(\mathrm{N}=176) \\
\text { Dark triad traits }(\mathrm{N}=176)\end{array}$} \\
\hline $\begin{array}{l}\text { Макиавел- } \\
\text { лизм } \\
\text { Machia- } \\
\text { vellianism }\end{array}$ & $-0.16^{*}$ & -0.03 & -0.01 & 0.05 & -0.07 & -0.11 & -0.01 \\
\hline $\begin{array}{l}\text { Нарцис- } \\
\text { сизм } \\
\text { Narcissism }\end{array}$ & -0.05 & 0.02 & -0.11 & -0.07 & -0.06 & -0.02 & -0.10 \\
\hline $\begin{array}{l}\text { Психо- } \\
\text { патия } \\
\text { Psycho- } \\
\text { pathy }\end{array}$ & $-0.24^{* *}$ & $-0.15^{*}$ & 0.04 & -0.03 & $-0.21^{* *}$ & $-0.22^{* *}$ & -0.08 \\
\hline
\end{tabular}




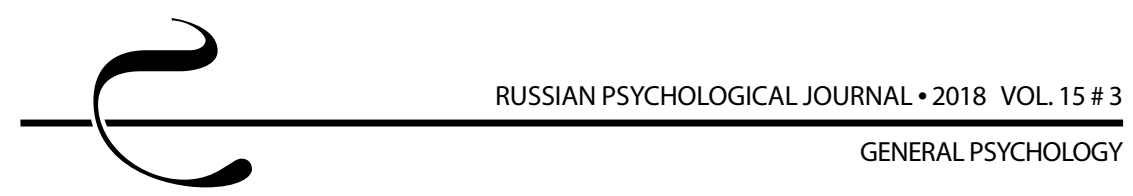

Индивидуализирующие МО заботы и справедливости оказались свободными от влияния социальной желательности. Однако умеренную подверженность тенденции к социальной желательности продемонстрировали шкалы сплачивающих МО («лояльность», «уважение», «чистота»). Наибольшую связь с МО показала шкала самообмана-приукрашивания, что, по-видимому, свидетельствует о слабой осознанности давления социальной оценки.

Поскольку большинство применявшихся методик показали значимые корреляции с тенденцией к социальной желательности, для анализа связей между ними использовались коэффициенты частной корреляции, позволяющие устранить обусловленную этой тенденцией общую дисперсию [28].

Ценности самопреодоления показали прямые связи с заботой и справедливостью, в то время как противоположные им эгоистические ценности самоутверждения показали обратные связи со всеми МО (таблица 3). Связанный со сплачивающими МО консерватизм проявился в прямых связях с ценностью сохранения, а открытость изменениям, напротив, показала с ними обратные связи. Аналогичные и вполне ожидаемые корреляции продемонстрировали также шкалы второго уровня: «этика автономии» и «этика сообщества».

Результаты корреляционного анализа подтвердили предположение о связи черт темной триады с МО (таблица 3). Для лиц с высокими показателями по шкале психопатии меньшую значимость имеют запреты на причинение вреда, они менее склонны сопереживать другим людям и проявлять заботу. Кроме того, они менее склонны соблюдать запреты на осквернение священных объектов и совершение поступков, вызывающих отвращение. Слабую обратную связь со шкалой заботы показала также шкала макиавеллизма, отражая присущее манипуляторам пренебрежительное отношение к потребностям и благополучию другого человека.

Анализ с помощью критерия Манна - Уитни показал, что различия в материальном положении, а также место проживания (город или село) не связаны с МО. Для сравнения МО в группах с различным уровнем религиозности использовался непараметрический критерий Джонкхиера - Терпстры, который позволяет выявить тенденции в изменении признака при сопоставлении трех и более упорядоченных выборок. На основе двух вопросов в анкете было выделено пять групп с различным уровнем религиозности. Результаты анализа с помощью критерия Джонкхиера - Терпстры, представленные в таблице 4, свидетельствуют о том, что рост уровня религиозности показывает статистически значимую связь со всеми МО, кроме заботы, а также со шкалой этики сообщества. Приведенные на рисунке 1 усредненные профили МО у лиц с разным уровнем религиозности наглядно демонстрируют тот факт, что для лиц с высокой религиозностью характерна примерно равная значимость как индивидуализирующих, так и сплачивающих МО, в то время 
ОБЩАЯ ПСИХОЛОГИЯ

как у лиц с низкой религиозностью сплачивающие МО оцениваются существенно ниже, чем индивидуализирующие.

Таблица 4. Результаты сравнения моральных оснований в группах с разным уровнем религиозности ( $N=282)$

Table 4. Comparison of moral foundations in groups with different levels of religiosity $(N=282)$

\begin{tabular}{|c|c|c|c|c|}
\hline $\begin{array}{l}\text { Шкалы } \\
\text { Scales }\end{array}$ & $\begin{array}{c}\text { Статистика } \\
\text { Ажонкхиера- } \\
\text { Терпстры } \\
\text { Jonckheere- } \\
\text { Terpstra } \\
\text { statistic }\end{array}$ & $\begin{array}{c}\text { СтанА. } \\
\text { откион. } \\
\text { статистики } \\
\text { Ажонкхиера- } \\
\text { Терпстры } \\
\\
\text { Jonckheere- } \\
\text { Terpstra } \\
\text { statistic } \\
\text { (standard } \\
\text { deviation) }\end{array}$ & $\begin{array}{c}\text { Стандартная } \\
\text { статистика } \\
\text { Ажонкхиера- } \\
\text { Терпстры } \\
\text { Jonckheere- } \\
\text { Terpstra } \\
\text { standard } \\
\text { statistic }\end{array}$ & $\begin{array}{c}\text { р-уровень } \\
\text { p-level }\end{array}$ \\
\hline $\begin{array}{l}\text { забота } \\
\text { Care }\end{array}$ & 14214 & 753.8 & -0.49 & $\begin{array}{l}\text { незначим } \\
\text { not } \\
\text { significant }\end{array}$ \\
\hline $\begin{array}{l}\text { СправеА- } \\
\text { ^ивость } \\
\text { Fairness } \\
\end{array}$ & 12983 & 753.4 & -2.13 & $<0.05$ \\
\hline $\begin{array}{l}\text { Аоя^ьность } \\
\text { Loyalty }\end{array}$ & 17148 & 754.1 & 3.40 & $<0.01$ \\
\hline $\begin{array}{l}\text { Уважение } \\
\text { Respect }\end{array}$ & 18478.5 & 753.7 & 5.17 & $<0.001$ \\
\hline $\begin{array}{l}\text { Чистота } \\
\text { Purity }\end{array}$ & 18403 & 754.2 & 5.06 & $<0.001$ \\
\hline $\begin{array}{l}\text { Этика } \\
\text { автономии } \\
\text { Ethics of } \\
\text { autonomy }\end{array}$ & 13454 & 755.4 & -1.50 & $\begin{array}{l}\text { незначим } \\
\text { not } \\
\text { significant }\end{array}$ \\
\hline $\begin{array}{l}\text { Этика } \\
\text { сооб- } \\
\text { щества } \\
\text { Ethics of } \\
\text { community }\end{array}$ & 18720.5 & 755.7 & 5.47 & $<0.001$ \\
\hline
\end{tabular}




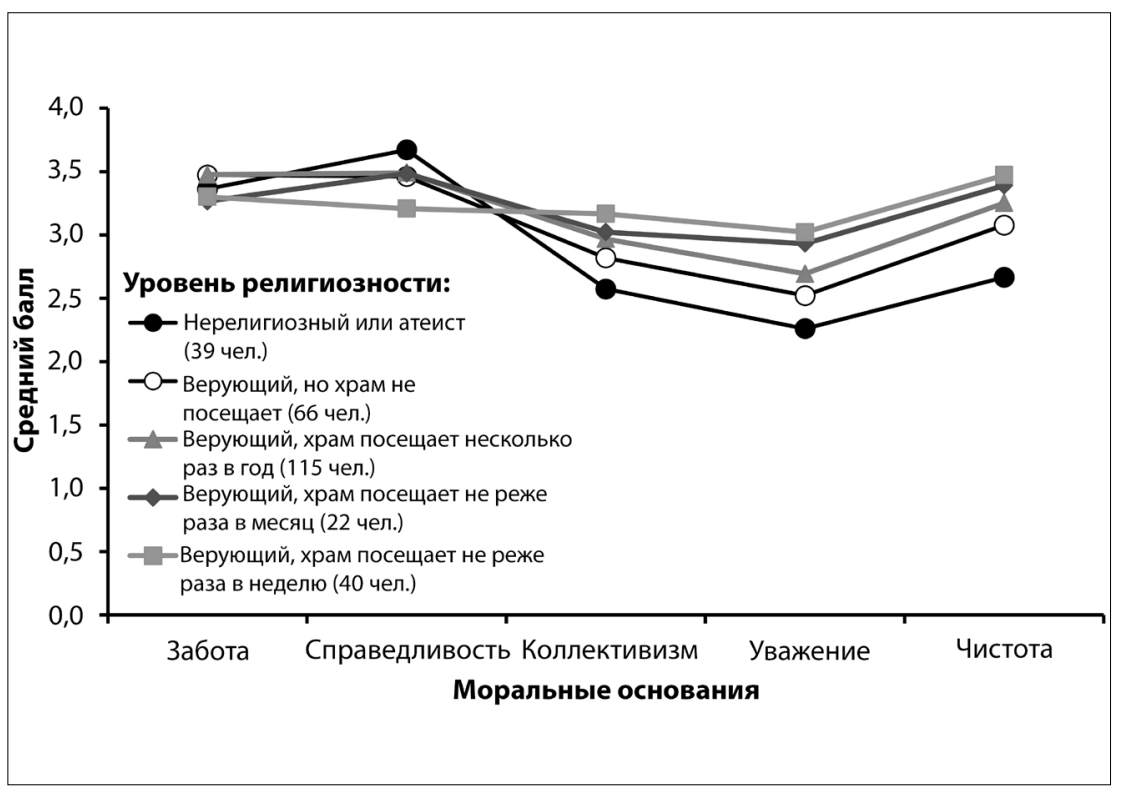

Рисунок 1. Профрили моральных оснований у ^иц с различным уровнем религиозности

Figure 1. Profiles of moral foundations in persons with different levels of religiosity

Корреляционный анализ показал, что люди старшего возраста выше оценивают сплачивающие МО. Коэффициент корреляции возраста со шкалой уважения составил 0.24 ( $<<0.001)$, со шкалой чистоты 0.26 ( $<<0.001)$, с этикой сообщества 0.24 ( $<$ < 0.001), при этом корреляция со шкалой справедливости была обратной, хотя и слабой $(r=-0.13 ; \mathrm{p}<0.05)$. Однако связь МО с возрастом в значительной мере обусловлена религиозностью, которая в нашей выборке выше у лиц старшего возраста. При контроле религиозности путем вычисления частных корреляций была обнаружена статистически значимая связь возраста только со шкалой чистоты $(r=0.13 ; \mathrm{p}<0.05)$. Существенные гендерные различия (d-Коэна > 0.40) были выявлены по МО заботы, уважения и индивидуализирующим моральным основаниям (таблица 5).

Для мужчин более характерным является консервативный профиль MO, когда оценка заботы и справедливости практически не отличается от оценки лояльности, уважения и чистоты. В усредненном профиле женщин оценка заботы и справедливости несколько выше, чем оценка лояльности и уважения. 
ОБЩАЯ ПСИХОЛОГИЯ

Таблица 5. Гендерные различия по шкалам опросника моральных оснований

Table 5. Gender differences for the MFQ scales

\begin{tabular}{|c|c|c|c|c|c|c|c|c|}
\hline \multirow{2}{*}{$\begin{array}{c}\text { Шкалы } \\
\text { MFQ-Ru } \\
\text { MFQ-Ru } \\
\text { scales }\end{array}$} & \multicolumn{2}{|c|}{$\begin{array}{l}\text { Среднее } \\
\text { значение } \\
\text { Mean score }\end{array}$} & \multicolumn{2}{|c|}{$\begin{array}{c}\text { Ста. } \\
\text { откио- } \\
\text { нение } \\
\text { Standard } \\
\text { deviation }\end{array}$} & \multirow{2}{*}{$\begin{array}{c}\text { U-крите- } \\
\text { рий } \\
\text { Манна- } \\
\text { Уитни } \\
\\
\text { Mann- } \\
\text { Whitney } \\
\text { U test }\end{array}$} & \multirow[t]{2}{*}{ Z } & \multirow[t]{2}{*}{$\begin{array}{c}\text { р-уровень } \\
\text { p-level }\end{array}$} & \multirow{2}{*}{$\begin{array}{l}\text { Размер } \\
\text { эфффекта } \\
\text { (d-Коэна) } \\
\text { Cohen's d } \\
\text { effect size }\end{array}$} \\
\hline & $\begin{array}{c}\text { K } \\
F \\
\end{array}$ & $\begin{array}{l}M \\
M\end{array}$ & $\begin{array}{c}K \\
F \\
F\end{array}$ & $\begin{array}{l}M \\
M\end{array}$ & & & & \\
\hline $\begin{array}{l}\text { 3абота } \\
\text { Care }\end{array}$ & 3.50 & 3.11 & 0.71 & 0.89 & 3729.5 & 3.12 & $<0.01$ & 0.51 \\
\hline $\begin{array}{l}\text { СправеА- } \\
\text { Аивость } \\
\text { Fairness } \\
\end{array}$ & 3.48 & 3.34 & 0.61 & 0.75 & 4549 & 1.24 & $\begin{array}{c}\text { незначим } \\
\text { not } \\
\text { significant } \\
\end{array}$ & 0.22 \\
\hline $\begin{array}{l}\text { ^оя^ь- } \\
\text { Ность } \\
\text { Loyalty }\end{array}$ & 2.90 & 3.10 & 0.70 & 0.91 & 4242 & -1.94 & $\begin{array}{l}\text { незначим } \\
\text { not } \\
\text { significant }\end{array}$ & 0.26 \\
\hline $\begin{array}{l}\text { Уважение } \\
\text { Respect }\end{array}$ & 2.62 & 2.92 & 0.72 & 0.77 & 3960.5 & -2.59 & $<0.01$ & 0.41 \\
\hline $\begin{array}{l}\text { Чистота } \\
\text { Purity }\end{array}$ & 3.20 & 3.23 & 0.79 & 0.72 & 5025.5 & -0.14 & $\begin{array}{l}\text { незначим } \\
\text { not } \\
\text { significant }\end{array}$ & 0.04 \\
\hline $\begin{array}{l}\text { Этика } \\
\text { автоно- } \\
\text { мии } \\
\text { Ethics of } \\
\text { autonomy }\end{array}$ & 3.49 & 3.23 & 0.60 & 0.75 & 3949.5 & 2.61 & $<0.01$ & 0.41 \\
\hline $\begin{array}{l}\text { Этика } \\
\text { сооб- } \\
\text { щества } \\
\text { Ethics of } \\
\text { commu- } \\
\text { nity }\end{array}$ & 2.91 & 3.08 & 0.63 & 0.67 & 4412 & -1.55 & $\begin{array}{l}\text { незначим } \\
\text { not } \\
\text { significant }\end{array}$ & 0.27 \\
\hline
\end{tabular}

Примечание: Ж-женшины, $M-$-мужчины.

Note: $F$-female, $M$ - male.

\section{Обсуждение результатов}

Результаты апробации MFQ-Ru показывают, что шкалы MO характеризуются проблематичной внутренней согласованностью, сопоставимой 


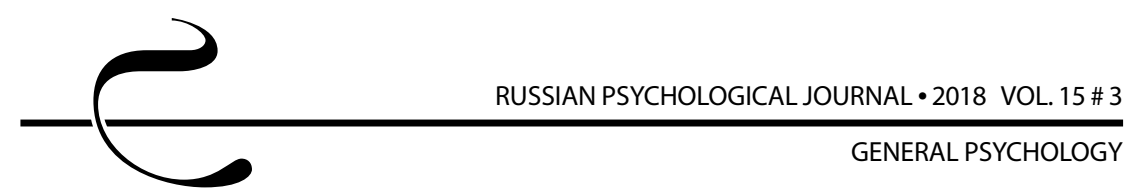

по величине с другими европейскими версиями методики [18, 19]. Весьма умеренная (хотя и несколько большая) надежность характерна также и для англоязычной версии, комментируя которую авторы MFQ отмечают: «хотя коэффициенты альфа не столь высоки, как для многих других шкал, они указывают на приемлемую (reasonable) внутреннюю согласованность с учетом того, что нашей целью было измерение широкого спектра моральных оценок с помощью небольшого числа пунктов в двух различных форматах» [см. 4, с. 371].

Обнаруженные прямые связи между шкалами индивидуализирующих и сплачивающих МО (не свойственные оригинальной версии опросника), по-видимому, стали причиной менее четкой факторной структуры опросника. Принимая во внимание аналогичные трудности в подтверждении факторной структуры опросника в исследованиях с другими европейскими версиями методики [см., например, 18, 19], можно предположить высокую культурную специфичность англоязычного текста методики, который нельзя рассматривать как универсальный, независимый от влияния культуры.

Хотя нам не удалось обнаружить других исследований связи МО с тенденцией к социальной желательности, вывод о наличии такой связи не является неожиданным. Обнаруженное давление социальной желательности на ответы испытуемых только в отношении сплачивающих МО может быть следствием коллективистских традиций в российском обществе.

Нами были получены предсказуемые, хорошо соответствующие теории и результатам зарубежных исследований связи с ценностями, свойствами темной триады, религиозностью, полом. Выявлены ожидаемые связи МО с ценностями самопреодоления и самоутверждения. Вывод о связи МО со свойствами темной триады полностью соответствует зарубежным данным [15], подтверждая присущий склонным к психопатии и макиавеллизму лицам «дефицит» морали. Связь МО с религиозностью также соответствует данным зарубежных исследований [29] и предсказаниям теории [30].

Таким образом, результаты проведенного исследования свидетельствуют, с одной стороны, о потенциале теории моральных оснований, проявляющемся в предсказуемых связях шкал опросника MFQ-Ru с другими психологическими и социально-демографическими признаками. С другой стороны, полученные результаты говорят о существенных психометрических проблемах, возникающих при попытке использовать опросник MFQ в версии, максимально приближенной по содержанию к оригиналу, что может быть следствием высокой культурной специфичности англоязычного текста методики. Решением этих проблем может стать разработка оригинального русскоязычного опросника моральных оснований. 
ОБЩАЯ ПСИХОЛОГИЯ

\section{Выводы:}

1. Предложенная версия MFQ-Ru характеризуется проблематичной надежностью шкал моральных оснований и высокой надежностью шкал второго уровня («этики автономии» и «этики сообщества»). Хотя факторная структура методики показывает удовлетворительное соответствие структуре оригинальной англоязычной версии, в целом она слабо соответствует теоретически предсказанному разделению заданий на шкалы «этики автономии» и «этики сообщества».

2. В пользу валидности шкал методики свидетельствуют связи оценок по шкалам первого и второго уровня с ценностями, чертами темной триады, религиозностью и полом, соответствующие зарубежным данным и положениям теории.

3. Выявленные недостатки опросника заставляют сделать вывод о необходимости разработки оригинального русскоязычного опросника моральных оснований.

\section{Благодарности}

Работа выполнена при финансовой поддержке РФФИ, проект № 18-013-00119 «Ценностные и моральные основы социального мировоззрения молодежи».

\section{Acknowledgments}

This work received funding from the Russian Foundation for Basic Research for studying Value and Moral Foundations for Social World View Among Youths (project no. 18-013-00119).

\section{Литература}

1. Graham J., Haidt J., Nosek B. A. Liberals and conservatives rely on different sets of moral foundations // Journal of Personality and Social Psychology. 2009. Vol. 96 (5). P. 1029-1046. DOI: 10.1037/a0015141

2. Haidt J., Bjorklund F. Social intuitionists answer six questions about moral psychology // Moral psychology. Vol. 2: The cognitive science of morality: Intuition and diversity / W. Sinnott-Armstrong (Ed.). Cambridge, MA, US: MIT Press, 2008a. P. 181-217.

3. Greene J., Haidt J. How (and where) does moral judgment work? //Trends in Cognitive Sciences. 2002. Vol. 6, Issue 12. P. 517-523. DOI: 10.1016/S13646613(02)02011-9

4. Graham J., Nosek B. A., Haidt J., lyer R., Koleva S., Ditto P. H. Mapping the moral domain // Journal of Personality and Social Psychology. 2011. Vol. 101 (2). P. 366-385. DOI: $10.1037 / \mathrm{a} 0021847$

5. Graham J., Haidt J., Koleva S., Motyl M., Iyer R., Wojcik S. P., Ditto P. H. Chapter Two - Moral Foundations Theory:The Pragmatic Validity of Moral Pluralism // 
Advances in Experimental Social Psychology. 2013. Vol. 47. P. 55-130. DOI: 10.1016/B978-0-12-407236-7.00002-4

6. Koleva S. P., Graham J., lyer R., Ditto P. H., Haidt J. Tracing the threads: How five moral concerns (especially Purity) help explain culture war attitudes // Journal of Research in Personality. 2012. Vol. 46, Issue 2. P. 184-194. DOI: 10.1016/j.jrp.2012.01.006

7. Боулби Д. Привязанность. М: Гардарики, 2003. 447 с.

8. де Вааль Ф. Истоки морали: в поисках человеческого у приматов. М.: Альпина нон-фикшн, 2014. 376 с.

9. Trivers R. L. The Evolution of Reciprocal Altruism //The Quarterly Review of Biology. 1971. Vol. 46, № 1. P. 35-57.

10. Козлова М. А., Козлов А. И. Истоки морали, ориентированной на индивида и группу: социально-психологический и естественно-научный аспекты // Психологический журнал. 2016. Т. 37, № 3. С. 60-70.

11. Сычев О. А., Беспалов А. М., Прудникова М. М., Власов М. С. Особенности моральных оснований у монгольских, немецких и российских подростков // Культурно-историческая психология. 2016. Т. 12, № 1. С. 85-96. DOI: $10.17759 /$ chp.2016120109

12. Shweder R. A., Much N. C., Mahapatra M., Park L. The "big three" of morality (autonomy, community, divinity) and the "big three" explanations of suffering // Morality and health / A. M. Brandt \& P. Rozin (Eds.). New York, NY: Routledge, 1997. P. 119-169.

13. Buchanan P. J. 1992 Republican National Convention Speech // Patrick J. Buchanan - Official Website. URL: http://buchanan.org/blog/1992-republicannational-convention-speech-148 (Accessed 03.04.2018).

14. Hunter J. D. Culture wars: The struggle to define America. New York: Basic Books, 1991. $432 \mathrm{p}$.

15. Jonason P. K., Strosser G. L., Kroll C. H., Duineveld J. J., Baruffi S. A. Valuing myself over others: The Dark Triad traits and moral and social values // Personality and Individual Differences. 2015. Vol. 81. P. 102-106. DOI: 10.1016/j. paid.2014.10.045

16. Radkiewicz P. Another look at the duality of the dual-process motivational model. On the role of axiological and moral origins of right-wing authoritarianism and social dominance orientation // Personality and Individual Differences. 2016. Vol. 99. P. 106-112. DOI: 10.1016/j.paid.2016.04.080

17. Kertzer J. D., Powers K. E., Rathbun B. C., lyer R. Moral Support: How Moral Values Shape Foreign Policy Attitudes //The Journal of Politics. 2014. Vol. 76, № 3. P. 825-840. DOI: $10.1017 /$ S0022381614000073

18. Jockel S., Dogruel L., Arendt K., Stahl H., Bowman N. German translation of the Moral Foundations Questionnaire - some preliminary results. URL: 
http://onmediatheory.blogspot.de/2010/07/german-translation-of-moralfoundations.html (Accessed 02.02.2018).

19. Nilsson A., Erlandsson A. The Moral Foundations taxonomy: Structural validity and relation to political ideology in Sweden // Personality and Individual Differences. 2015. Vol. 76. P. 28-32. DOI: 10.1016/j.paid.2014.11.049

20. Yilmaz O., Harma M., Bahçekapili H. G., Cesur S. Validation of the Moral Foundations Questionnaire in Turkey and its relation to cultural schemas of individualism and collectivism // Personality and Individual Differences. 2016. Vol. 99. P. 149-154. DOI: $10.1016 /$ j.paid.2016.04.090

21. Questionnaires // moralfoundations.org. URL: http://moralfoundations.org/ questionnaires (Accessed 05.07.2018).

22. Швари Ш., Бутенко Т. П., Седова Д. С., Липатова А. С. Уточненная теория базовых индивидуальных ценностей: применение в России // Психология. Журнал Высшей школы экономики. 2012. Т. 9, № 1. С. 43-70.

23. Егорова М. С., Ситникова М. А., Паршикова О. В. Адаптация Короткого опросника Темной триады // Психологические исследования. 2015. T. 8, № 43. C. 1. URL: http://psystudy.ru/index.php/num/2015v8n43/1181egorova43.html (дата обращения: 22.03.2016).

24. Осин Е. Н. Проблема социальной желательности в исследованиях личностного потенциала // Личностный потенциал: структура и диагностика. М.: Смысл, 2011. С. 454-468.

25. Global Index of Religiosity and Atheism. Press Release. URL: https://docslide. us/documents/global-index-of-religiosity-and-atheism.html (Accessed 15.08.2018).

26. DeVellis R. F. Scale Development: Theory and Applications. Newbury Park, CA: Sage Publ., 1991. 121 p.

27. Lorenzo-Seva U., ten Berge J. M. Tucker's Congruence Coefficient as a Meaningful Index of Factor Similarity // Methodology. 2006. Vol. 2, Issue 2. P. 57-64. DOI: $10.1027 / 1614-2241.2 .2 .57$

28. Гласс Д., Стэнли Д. Статистические методы в педагогике и психологии. М.: Прогресс, 1976. 496 c.

29. Johnson K. A., Hook J. N., Davis D. E., Van Tongeren D. R., Sandage S. J., Crabtree S. A. Moral foundation priorities reflect U.S. Christians' individual differences in religiosity // Personality and Individual Differences. 2016. Vol. 100. P. 56-61. DOI: 10.1016/j.paid.2015.12.037

30. Graham J., Haidt J. Beyond Beliefs: Religions Bind Individuals Into Moral Communities // Personality and Social Psychology Review. 2010. Vol. 14, Issue 1. P. 140-150. DOI: $\underline{10.1177 / 1088868309353415}$ 


\section{References}

1. Graham J., Haidt J., Nosek B. A. Liberals and conservatives rely on different sets of moral foundations. Journal of Personality and Social Psychology, 2009, V. 96 (5), pp. 1029-1046. DOI: 10.1037/a0015141

2. Haidt J., Bjorklund F. Social intuitionists answer six questions about moral psychology. In: W. Sinnott-Armstrong (ed.) Moral psychology. Vol. 2: The cognitive science of morality: Intuition and diversity. Cambridge, MA, US, MIT Press, 2008, pp. 181-217.

3. Greene J., Haidt J. How (and where) does moral judgment work? Trends in Cognitive Sciences, 2002, V. 6, Issue 12, pp. 517-523. DOI: 10.1016/S13646613(02)02011-9

4. Graham J., Nosek B. A., Haidt J., lyer R., Koleva S., Ditto P. H. Mapping the moral domain. Journal of Personality and Social Psychology, 2011, V. 101 (2), pp. 366-385. DOI: 10.1037/a0021847

5. Graham J., Haidt J., Koleva S., Motyl M., Iyer R., Wojcik S. P., Ditto P. H. Chapter two - moral foundations theory: The pragmatic validity of moral pluralism. Advances in Experimental Social Psychology, 2013, V. 47, pp. 55-130. DOI: 10.1016/B978-0-12-407236-7.00002-4

6. Koleva S. P., Graham J., lyer R., Ditto P. H., Haidt J. Tracing the threads: How five moral concerns (especially Purity) help explain culture war attitudes. Journal of Research in Personality, 2012, V. 46, Issue 2, pp. 184-194. DOI: 10.1016/j.jrp.2012.01.006

7. Bowlby J. Attachment. New York, Basic books (Russ. ed.: Boulbi D. Privyazannost'. Moscow, Gardariki Publ., 2003. 447 p.).

8. de Waal F. The bonobo and the atheist: In search of humanism among the primates. WW Norton \& Company, 2013 (Russ. ed.: de Vaal' F. Istokimorali: vpoiskakh chelovecheskogo u primatov. Moscow, Al'pina non-fikshn Publ., 2014. 376 p.).

9. Trivers R. L. The evolution of reciprocal altruism. The Quarterly Review of Biology, 1971, V. 46, no. 1, pp. 35-57.

10. Kozlova M. A., Kozlov A. I. Origins of morality focused on individuals and groups: Socio-psychological and natural scientific aspects. Psikhologicheskii zhurnal, 2016, V. 37, no. 3, pp. 60-70 (in Russian).

11. Sychev O. A., Bespalov A. M., Prudnikova M. M., Vlasov M. S. Characteristics of moral foundations in Mongolian, German, and Russian adolescents. Kul'turno-istoricheskaya psikhologiya - Cultural-historical psychology, 2016, V. 12, no. 1, pp. 85-96 (in Russian). DOI: 10.17759/chp.2016120109

12. Shweder R. A., Much N. C., Mahapatra M., Park L. The "big three" of morality (autonomy, community, divinity) and the "big three" explanations of suffering. In: A. M. Brandt \& P. Rozin (eds.) Morality and health. New York, NY, Routledge, 1997, pp. 119-169. 
13. Buchanan P. J. 1992 Republican national convention speech. (Online) Patrick J. Buchanan - Official Website. Available at: http://buchanan.org/blog/1992republican-national-convention-speech-148 (Accessed 03 April 2018).

14. Hunter J. D. Culture wars: The struggle to define America. New York: Basic Books, 1991. $432 \mathrm{p}$.

15. Jonason P. K., Strosser G. L., Kroll C. H., Duineveld J. J., Baruffi S. A. Valuing myself over others: The Dark Triad traits and moral and social values. Personality and Individual Differences, 2015, V. 81, pp. 102-106. DOI: 10.1016/j. paid.2014.10.045

16. Radkiewicz P. Another look at the duality of the dual-process motivational model. On the role of axiological and moral origins of right-wing authoritarianism and social dominance orientation. Personality and Individual Differences, 2016, V. 99, pp. 106-112. DOI: 10.1016/j.paid.2016.04.080

17. Kertzer J. D., Powers K. E., Rathbun B. C., lyer R. Moral support: How moral values shape foreign policy attitudes. The Journal of Politics, 2014, V. 76, no. 3, pp. 825-840. DOI: 10.1017/S0022381614000073

18. Jockel S., Dogruel L., Arendt K., Stahl H., Bowman N. German translation of the Moral Foundations Questionnaire - some preliminary results. Available at: http://onmediatheory.blogspot.de/2010/07/german-translation-of-moralfoundations.html (Accessed 02 February 2018).

19. Nilsson A., Erlandsson A. The Moral Foundations taxonomy: Structural validity and relation to political ideology in Sweden. Personality and Individual Differences, 2015, V. 76, pp. 28-32. DOI: 10.1016/j.paid.2014.11.049

20. Yilmaz O., Harma M., Bahçekapili H. G., Cesur S. Validation of the Moral Foundations Questionnaire in Turkey and its relation to cultural schemas of individualism and collectivism. Personality and Individual Differences, 2016, V. 99, pp. 149-154. DOI: $10.1016 /$ j.paid.2016.04.090

21. Questionnaires. (Online) moralfoundations.org. Available at: http://moralfoundations.org/questionnaires (Accessed 05 July 2018).

22. Shvarts Sh., Butenko T. P., Sedova D. S., Lipatova A. S. A refined theory for basic individual values: Application in Russia. Psikhologiya. Zhurnal Vysshei shkoly ekonomiki - Psychology: Journal of Higher School of Economics, 2012, V. 9, no. 1, pp. 43-70 (in Russian).

23. Egorova M. S., Sitnikova M. A., Parshikova O. V. Modification of the Short Dark Triad questionnaire. Psychological Studies, 2015, V. 8, no. 43, p. 1 (in Russian). URL: http://psystudy.ru/index.php/num/2015v8n43/1181-egorova43.html (Accessed 22 March 2016).

24. Osin E. N. The problem of social desirability in studying personal potential. In: Lichnostnyi potentsial: struktura i diagnostika [Personal potential: Structure and diagnostics]. Moscow, Smysl Publ., 2011, pp. 454-468. 
25. Global index of religiosity and atheism. Press Release. (Online) Available at: https://docslide.us/documents/global-index-of-religiosity-and-atheism. html (Accessed 15 August 2018).

26. DeVellis R. F. Scale development: Theory and applications. Newbury Park, CA, Sage Publ., 1991. $121 \mathrm{p}$.

27. Lorenzo-Seva U., ten Berge J. M. Tucker's congruence coefficient as a meaningful index of factor similarity. Methodology, 2006, V. 2, Issue 2, pp. 57-64. DOI: 10.1027/1614-2241.2.2.57

28. Glass G. V. \& Stanley J. C. Statistical methods in education \& psychology. Englewood Cliffs, N.J., Prentice-Hal, 1970 (Russ. ed.: Glass D., Stenli D. Statisticheskie metody v pedagogike i psikhologii. Moscow, Progress Publ., 1976. 496 p.).

29. Johnson K. A., Hook J. N., Davis D. E., Van Tongeren D. R., Sandage S. J., Crabtree S. A. Moral foundation priorities reflect U.S. Christians' individual differences in religiosity. Personality and Individual Differences, 2016, V. 100, pp. 56-61. DOI: 10.1016/j.paid.2015.12.037

30. Graham J., Haidt J. Beyond beliefs: Religions bind individuals into moral communities. Personality and Social Psychology Review, 2010, V. 14, Issue 1, pp. 140-150. DOI: $10.1177 / 1088868309353415$ 